\title{
Role of Genetic and Expression Profiling in Pharmacogenomics: The Changing Face of Patient Management
}

\author{
Vincenzo Pagliarulo*, Ram H. Datar, Richard J. Cote \\ University of Southern California, Department of \\ Pathology, 2011 Zonal Avenue, HMR 312C, \\ Los Angeles, CA 90033, USA
}

\begin{abstract}
As the determination of gene sequences and their function gains speed at the dawn of the third millennium, biomedical research efforts are oriented towards definition of the genetic and molecular expression patterns that may drive different disease. A major part of these efforts is addressed to the definition of inter-individual variations that are expected to become integral for treatment planning, in terms of efficacy and adverse effects of drugs. It is this thrust on genome-based 'rational therapeutics' that is hoped to progressively lead to the era of 'personalized medicine'. This approach uses the technological expertise from genomics and functional genomics to define, predict and monitor the nature of the response of an individual to drugs, and to rationally design newer drugs. In the present review we will conduct our readers through an understanding of the fundamentals of pharmacogenomics and of the technologies currently available that are advancing this relatively new science. Conversely, there are issues raised that concern how medical practice is preparing itself to implement new alternatives for therapeutical interventions and finally, how to respect patient confidentiality and rights.
\end{abstract}

\section{Introduction}

Genetic variation impacts upon biochemical and cellular functions. While all human beings share nearly $99 \%$ of their DNA sequence, the small number of inter-individual genetic differences can cause biochemical changes in important pathways of the body, including drug metabolism. This change may affect how a person will respond to a drug, such as increase or decrease in the adverse reaction or the effectiveness of therapy. Individual variation in response to drugs is a substantial clinical problem, which includes failure to respond to a drug, adverse drug reactions and undesirable drug-drug interactions when several drugs are taken concomitantly. The clinical consequences, which

*For correspondence. Email datar@usc.edu; Tel. +1-323 442-3478; Fax. +1-323 442-1154. range from patient discomfort through serious clinical illness to the occasional fatality, have substantial impact on healthcare systems the world over. Thus, for example, in Britain 1 in 15 hospital admissions is due to adverse drug reactions (editorial. Adverse Drug. React. Toxicol. Rev., 1997), while in the US, as many as 106,000 patients die and 2.2 million are injured each year by adverse reactions to prescribed drugs (Lazarou, et al., 1998). Significant proportion of this individuality in drug response is inherited. The research area that defines the genetic basis for variability in drug response is known as pharmacogenetics. Pharmacogenomics, on the other hand, is a relatively more global field, which uses knowledge from genetic variability at the levels of single nucleotide polymorphism (SNP), the microsatellite repeats and inter-individual variations due to transcription and translation (all resulting as a fall-out from data of genomics) to rationally develop newer drugs. Thus, the research in pharmacogenomics is currently evolving in four main directions:

- Identifying specific disease-associated genes, allelic variants or gene products (which could act as targets for drugs),

- Identifying gene or allelic variants that affect individual response to current drugs (allowing patient-specific drug stratification),

- Identifying disease-associated molecular expression profiles to pinpoint targets in various pathways, and finally,

- To design and develop individual-optimized drugs based on differential genetic and expression characters

Several types of genome maps have already been completed, and a working draft of the entire human genome sequence was announced in June 2000 (The international human genome mapping consortium, 2001). The confirmation that there might be fewer than 30,000 proteincoding genes in the human genome is one of the key results of the recent human genome project draft. About $10 \%$ of human genes might correspond to potential drug targets related to disease of socio-economical importance. Given the realistic estimate that each of the top 100 biotechpharmaceutical companies throughout the world might work to develop 30 candidate drugs each, the pharmaceutical industry is now facing a new challenge with only 3000 candidate genes to work from (Claverie, 2001). Only a few years of fierce competition should suffice for developing leads for all of these candidates. Since these drugs might prove inefficacious due to genetic differences that underlie drug metabolism, limiting the pharmaceutical 
target search to only 3000-odd drug targets might underserve the patients and seriously undermine the long-term growth and economic viability of the pharmaceutical industry itself. It is, therefore, in the interest of (and indeed a duty of) all concerned -medical researchers, pharmaceutical industry and the physicians - that newer ways of designing medicines are found that address the individual variations in gene expression profiles. The development of personalized treatments based on genomic polymorphisms and individual transcriptome patterns is thus quickly becoming a necessary driving force for pharmaceutical innovation. In this regard, it is hoped that this pharmacogenomic approach may lead to more focused and quicker clinical trials and to individually tailored treatment regimens. The patients can be screened to identify which therapeutic option will be apt for their genetic and physiological makeup and then monitored for their response. This approach is likely to have radical impact on healthcare and clinical management of diseases. The present review will discuss available technologies with their benefits and limitations, and the future directions for patient management.

\section{Genetic Profiling To Understand Differential Patient Response To Drugs}

SNPs are single variations, or polymorphic changes in the nucleotide sequences that are located at specific points throughout a person's genomic DNA. These commonest genetic polymorphisms are being catalogued in a mammoth international effort, SNP Consortium, and are expected to yield crucial information for new drug development and individualized drug prescription. It must, however, be borne in mind that once a suspected SNP has been located, the challenging work has only just begun. In order for the SNP to be clinically usable, the identification must be followed by SNP confirmation, its functional assessment and evaluation of its pharmacological and toxicological impact. The SNP detection and confirmation require use of SNP scoring technologies, either direct or indirect (Grant et al., 2001). Direct scoring technologies include DNA sequencing and use of DNA polymerase to directly detect the polymorphic nucleotide. Indirect scoring technologies use hybridization to identify base composition of the SNP by the presence or absence of binding of one of two specific DNA sequences variant at only one base. While the hybridization approaches are harder to optimize, they are more accurate than the direct detection technologies. Combination of the two methodologies involving hybridization coupled to an enzymatic reaction offers both advantages, but suffers in time taken, and hence the throughput. The read-out methods comprise fluorescence measurement, colorimetry, and mass spectrometry using technologies such as capillary electrophoresis, mass spectroscopy, microbeads and microchips.

The role of SNPs and microsatellite instability in disease susceptibility has been studied extensively and reviewed (Peltomaki, 2001; Bowater et al., 2001). We will briefly describe the salient instances of such genetic variations, which influence the disease progression and clinical management. Depending upon sequence variations, the biochemistry of drug-metabolizing liver enzymes has been shown to vary between individuals (Wolf et al., 2000). When such an enzyme functions less efficiently, the patient won't be able to efficiently metabolize the drug and may be at greater risk of overdosing. Conversely, if another patient has genetic sequence that makes the liver enzyme function as extensive metabolizer, the patient may need a higher dose of the drug to be effective. Three specific examples that we discuss here are polymorphisms in the genes for hydroxylase CYP2D6 (a component of Cytochrome P450 system), thiopurine methyl transferase (TPMT) and UDP-glucuronosyl transferase (UGT). In addition, there are examples of alterations (either at genetic or expression level) in genes pivotal in the pyrimidine biosynthesis pathway. We shall briefly address the variations in genes for enzymes that influence metabolism of anti-cancer drug 5-Fluorouracil (5FU) in this regard.

\section{CYP2D6 Polymorphism}

An early observation of differential drug metabolism in individuals was that the antituberculosis drug isoniazid might be either slowly or rapidly acetylated (Evans et al., 1960). The acetylation polymorphism is important for many drugs. The cytochrome P450 enzymes, encoded by members of a multigene family, are primarily produced in liver and are responsible for metabolic processing and scavenging of majority of currently used medicines. Polymorphisms in genes encoding different members of this enzyme family have been known to affect patient response and impact on dosage requirements. Thus, for example, cytochrome P450 CYP2C9 gene polymorphism affects clearance of warfarin compounds, while that in CYP2D6 gene can inhibit conversion of prodrug codeine to analgesic drug morphine (Wolf et al., 2000). The CYP2D6 gene polymorphism has been extensively studied because numerous drugs prescribed for neurological, psychiatric and cardiovascular diseases are metabolized by the product of CYP2D6 gene, debrisoquine hydroxylase.

Debrisoquine is an antihypertensive agent that is no longer on the market owing to its induction of orthostatic hypotension. The adverse effect was linked to the lack of an enzyme debrisoquine hydroxylase and the affected subjects were classified as poor metabolizers (PM) of debrisoquine, as opposed to normal responders whose enzyme was shown to be processive (extensive metabolizers, EM) (Mahgoub et al., 1977).

Heim and Meyer developed a method to analyze the common CYP2D6 genotypes (Heim et al., 1990). The PM phenotype due to inactive debrisoquine hydroxylase can be predicted in as many as $7.4 \%$ of Caucasians (Broly et al., 1991; Dahl et al., 1992). Genetic profiling has a potential to predict drug toxicity, as the PM may accumulate higher than expected plasma concentrations of parent compound and thus suffer exaggerated effect or even toxicity. Identifying such $\mathrm{PM}$ patients can prevent supra-therapeutic dosage regimen and concentration-dependent side effects (Dahl et al., 2000). On the other hand, the EM patients if not so identified may receive insufficient drug treatment because a standard dose is too low compared that required 
by the individual. Such differential drug metabolism in patients can also occur as a result of gene amplification polymorphism for CYP2D6. This is well exemplified in the case of Nortriptyline, an antidepressant or mood elevator drug used to treat mental depression, which is metabolized by CYP2D6. Bertilsson et al showed that PM patients inheriting single copy of CYP2D6 gene require as low as $10-20 \mathrm{mg}$ as daily dose of the drug, while the EM patients inheriting multiple copies of CYP2D6 gene require as high as $500 \mathrm{mg}$ per day (Bertilsson et al., 1993).

\section{TPMT Polymorphism}

Anti-cancer drugs 6-thioguanine and 6-mercaptopurine are metabolized by thiopurine methyl transferase. These are the drugs of choice for childhood leukemia. Although TPMT polymorphism is rarer compared to CYP2D6 polymorphism ( $1 \%$ Caucasians homozygous for the polymorphism), distinguishing between the poor and extensive metabolizers allows identifying those who might have severe hematopoietic toxicity due to slow drug elimination and lowering their dosage accordingly, while predicting those patients who will need higher effective dose to compensate for faster metabolism (Weinshilboum 2001).

\section{UGT Polymorphism}

Topoisomerase-I inhibitor irinotecan (CPT-11 or Camptosar) used in the treatment of metastatic colorectal cancer is characterized by severe and unpredictable diarrheal episodes. A specific UGT isoform, UGT1A1, is responsible for glucuronide conjugation of the active metabolite of CPT-11 (SN-38). The (TA $)_{7}$ TAA allele sequence in the promoter region of UGT1A1 gene is polymorphic and is found at high frequency (35\%) in Caucasian population. Screening for this polymorphism has been suggested as an effective diagnostic tool to predict irinotecan induced toxicity and definition of appropriate dosages based upon the genotype (lyer et al., 1998; Iqbal et al., 2001).

\section{Genetic Basis of Differential 5-FU Metabolism}

Typically, the pharmacologic effects of drugs are not impacted upon by single genes; rather, a result of several genes that encode proteins influencing drug metabolism, disposition, efficacy and elimination. In case of the anticancer drug 5-FU, for example, the enzymes that are crucial for metabolism and elimination include dihydro pyrimidine dehydrogenase (DPD), thymidylate synthase (TS) and dihydro folate synthase (DHFR). When used in cancer patients as a chemotherapeutic, 5-FU is anabolized by UPRT to bio-active F-dUMP (Fluoro deoxy Uridine Mono Phosphate), which competes with the cellular dUMP in order to form a ternary complex with the enzyme TS and the cofactor $\mathrm{CH}_{2} \mathrm{THF}(5,10$-methylene tetra hydro folate). This results in short-circuiting the dUMP-dTTP-DNA synthesis pathway, killing the cell. The excess of $5-\mathrm{FU}$ is catabolized by the enzyme DPD to an inactive form dHFU (di Hydro Fluoro Uridine), leading to clearance of excess 5-FU that otherwise could be potentially toxic (Van Triest et al., 2000).

Genetic anomalies in the expression of any of the three enzymes pivotal in 5-FU metabolism can adversely affect the efficacy and toxicity of 5-FU. Thus, for example, nearly $60 \%$ of cancer patients who exhibit severe, life-threatening or fatal 5-FU-related toxicity show germ-line mutations in the DPD-encoding gene (DPYD), including missense and frameshift mutations and a splice site mutation. This toxicity is the result of failure of DPD-mediated clearance of excess $5-F U$ in these patients. DPD deficiency can be examined in lymphocytes in peripheral blood. DPD deficiency determination, thus, may allow patient risk stratification for 5 -FU toxicity. For at-risk patients, either variation in the dosage of $5-\mathrm{FU}$, or alternative drug regimens can be employed. Another candidate enzyme gene is TS. TS expression has been shown to be predictive of response to 5-FU therapy in colorectal cancer (Gorlick et al., 1998). Even among gastric cancer patients who received 5-FU based chemotherapy, the overall 5-year survival rate was substantially lower for patients with TS-positive tumors than for patients with TS-negative tumors. High TS expressing gastric tumors were chemoresistant, suggesting that increased TS expression may be a means to escape 5-FU sensitivity (Tsujitani et al., 2000). Gain in the chromosomal region 18p11.32 containing the TS gene was detected by $\mathrm{CGH}$ in three drug-resistant cancer cell lines (Rooney et al., 1998). Di-hydro folate, the product of TS action, is converted to tetra hydro folate by the enzyme DHFR. The DHFR gene has been classically shown to be amplified to several hundred copies in the presence of methotrexate. Quite interestingly, the mismatch repair gene MSH3 is linked by a shared promoter with DHFR, connecting two pathways with key roles in DNA metabolism. This implies potential increase in mutability when tumors are treated with methotrexate, resulting in increase in the frequency of subsequent mutations that may influence the tumor's drug sensitivity or aggressiveness (Drummond 1999). Together, these findings emphasize the immense potential of pharmacogenomics and the significance of gene expression profiling. It should be noted, however, that the relatively large amount of tissue required for each enzyme assay imposes limitations in clinical utility. These limitations include the facts that the number of specific assays that can be performed for small primary tumors are small and that the assays are labor intensive and expensive as they currently are performed, and not well suited for testing in most clinical laboratories. Polymerase chain reaction (PCR) based assays are ideal for use with small tissue specimens such as needle biopsies (Rolfs et al., 1992). Of particular interest to examine RNA levels of expression has been the development of quantitative PCR (Q-PCR) methods that theoretically permit quantitation of the relative or actual copy number of transcripts from a specific gene (Volkenandt et al., 1992; Lenz et al., 1995). Recently, feasibility of using this Q-PCR approach to examine 5-FU efficacy in specific patients has been demonstrated (Johnston et al., 1995; Leichman et al., 1997; Salonga et al., 2000). Discussion of salient technologies for such gene expression profiling follows a little later.

Pharmacogenomics also finds application in cases of patients with infectious diseases. The HIV genotype/ phenotype assay is an example of pharmacogenomics, albeit genetic signatures tested are not from human DNA, but from viral DNA. HIV isolated from a patient yields 
sequence information that reveals any changes that will lead to resistance against antiviral therapeutics. This information is used by the physician to determine the appropriate treatment of the patient.

\section{Molecular Profiling}

Molecular profiling, an approach for studying the activity of many genes or proteins in parallel is evolving in the past few years, mainly because of the recognition that there is a tiered complexity in biological systems which cannot be unraveled by studying one gene or one protein at a time. Attempts to obtain global panoramic view of mRNA, protein patterns, and DNA alterations in various tissues and pathogenic processes, coupled with revolutionary data mining and technological advances, hold great promise to elucidate molecular pathology. In the end, they will yield new diagnostic and therapeutic targets for clinical intervention. Molecular profiling thus is an embodiment of the concept of translational medicine. The profiling provides molecular signatures of the specific tissues or cells derived from clinical samples. Dissection of molecular pathways that lead to pathogenesis allows design novel agents for the treatment of cancer. Development of faster highthroughput screening technologies requiring minimal human intervention is expected to allow increase in the speed for identification of targets for such rational drugs. The DNA microarray and expression microarray are among the commonest high-throughput technologies that are being widely used in many laboratories (Pease et al., 1994; Southern et al., 1994; Brown et al., 1999). Applications of these and other similar technologies are briefly described below.

\section{Genomic Profiling}

Microarray for Genetic Analysis of Polymorphisms

Use of microarray has transformed the fields of both genetic analyses for SNP and expression profiling in recent years. All variations of assembling DNA arrays derive from seminal experiments from the laboratory of Ed Southern nearly three decades ago (Southern, 1975). In the most common format of microarray, defined "probe" sequences are immobilized or tethered on solid phase such as glass slides or silicon chips, and the hybridization of the unknown "target" nucleic acid from solution phase with the 'probes' is detected by virtue of one or the other of various 'labels' on 'targets'. Microarrays are now widely used for DNA sequence analysis for SNP detection (Hacia et al., 1996; Lockhart et al., 1996). Thus, multitude of gene polymorphisms can be analyzed in parallel from a given sample in each assay, allowing a rapid scan of an entire genome for polymorphic variants. Population-wide polymorphism distributions and allele frequencies can be analyzed by directly comparing parallel tests on many different organisms or tissues. A functional genotyping microarray includes all the four components in optimized format: the array probe set, labeled targets, a sensitive detection method and an automated data analysis method.
Expression Profiling Technologies

Since gene expression data can be differentially expressed as comparison of expression of various genes within a sample or that of expression of the same gene across different samples, distinct terminologies have been coined to describe this subtle difference. Thus, when the gene expression data is represented as a matrix of samples versus gene expression levels, the set of expression levels of different genes for a given sample is called an expression signature of the particular sample, while the set of expression levels for a given gene across different samples is called an expression profile of the gene. While both are obviously important, in the present review we will discuss mainly the profiling aspects, since these are more relevant for pharmacogenomics which essentially deals with variability across clinical samples from different patients.

\section{a) Transcriptional Profiling}

\section{Differential Display}

Invented in 1992 by Liang and Pardee (Liang and Pardee 1992), mRNA differential display technology works by systematic amplification of the $3^{\prime}$ termini of mRNAs and resolution of those fragments on a DNA sequencing gel. Reverse transcription is carried out using anchored primers designed to anneal to and extend differentially from the $5^{\prime}$ boundary of the poly-A tails for transcripts, and PCR amplification is carried out with upstream arbitrary primers. The mRNA sub-populations are visualized by denaturing polyacrylamide electrophoresis to allow direct side-by-side comparison of most of the mRNAs between or among related cells. The differential display method permits visualization of all the expressed genes, both known and unknown. In fact, the ability to discover newer genes based upon limited 3' transcript end sequence information makes it one of the earliest 'open systems' of transcript profiling (Green et al, 2001). The limitation, however, is that the technology is 'platform inconsistent' in that significant human intervention is required at various stages, thus limiting its automation and hence high-throughput.

\section{Microarray for Gene Expression}

Expression microarrays as used currently are capable of generating vast databases of information that provide highresolution snapshots of cellular activity. They can be particularly powerful in the analysis of cellular signaling pathways. Either the complementary DNA (cDNA) or oligonucleotides are used as 'probes' (Ekins et al., 1999). While 20-50 mers are used in oligonucleotide arrays, cDNA arrays are usually 500-1000 nucleotide-long products of PCR generated using either vector-specific or gene-specific primers. More than 30,000 cDNAs can be fitted onto the surface of a conventional microscope slide. However, the high costs associated with commercially available oligonucleotide arrays or the tedium as well as cost of cDNA clone generation limit the value of both these formats for general academic laboratory use. However, rather welcome competition among numerous vendors is seen continually decreasing prices for oligonucleotide synthesis, making spotted long-oligonucleotide arrays a practical alternative for the future. 
In a common example, different fluorescent dyes (such as Cy3 and Cy5) are used for labeling of mRNA 'targets' from two different cell populations, mixed and hybridized to the same oligonucleotide 'probe' array, and the resulting competitive binding of the targets to the arrayed sequences is measured as follows. After post-hybridization washes, the slide is scanned using two different wavelengths and the intensity of the same spot in both fluorescence channels is compared. A measurement of the ratio of transcript levels for each gene is thus obtained. In order to prepare more sensitive and quantitative target in cases where the quantity of RNA is not limited, incorporation of fluorescently labeled nucleotides during synthesis of the first strand of CDNA is resorted to, as it provides the most linear relationship between starting material and labeled product. However, since most protocols require between 25-100 $\mu$ g total RNA, which is often problematic in studies using primary tissues, procedures to increase sensitivity and reduce the amount of RNA are employed. Thus, either target amplification is achieved by in vitro transcription, or post-hybridization signal amplification is achieved using labeled antibodies or molecules carrying larger numbers of fluorophores, such as branched DNA dendrimers (Murakami et al., 2001) or tyramide derivatives (Capaldi et al., 2000). Summarizing, despite significant technological innovations in various array formats, significant impediments must be surmounted before this versatile technology can support routine, reliable, high-throughput assays.

\section{Standardized RT-PCR}

Although the high-density array technology has potential for large-scale measurement of all human genes simultaneously, it requires at least $1 \mu \mathrm{g}$ of RNA for each experiment in its current form (Lockhart et al., 1996). Willey and collaborators at Rochester University have developed a modified quantitative method for competitive RT-PCR that allows simultaneous measurement of many genes using nanogram amounts of cDNA (Apostolakos et al., 1994; Willey et al., 1998). The transcript levels are expressed as numerical values per million molecules of $\beta$ actin, thus allowing intra-sample and inter-sample comparisons. While this method is still 'platforminconsistent' as it requires substantial human intervention and will benefit from automation, it does permit inexpensive generation of standardized expression profiles.

\section{b) Protein Pathway Profiling}

Although transcript profiling may provide an idea about gene activity, it may not accurately parallel the activity of the protein product of a gene (Hancock et al., 1999; Luo et al., 1999; Gygi et al., 1999; Humphery-Smith et al., 1997). Apart from cataloging the protein moieties themselves, protein profiling can yield information about various pivotal post-translational protein modifications as well, which include phosphorylation, acetylation, sulphation or glycosylation. Although majority of protein identification still continues to be by two-dimensional (2D) gel electrophoresis (Page et al., 1999; Banks et al., 2000; Emmert-Buck et al., 2000), many new technologies such as high-throughput protein arrays are being developed for high-throughput protein characterization and discovery (Ekins et al., 1991; Chiem et al., 1998; Hancock et al., 1999; Rowe et al., 1999; Paweletz et al., 2000; EmmertBuck et al., 2000; Arenkov et al., 2000), which are expected to replace the tedium and large protein loads typically associated with the $2 \mathrm{D}$ gels. Other novel formats include Ciphergen systems based on MALDI-TOF mass spectrometry (Davies 2000; Boyle et al., 2001), and Biacore detection systems based upon surface plasmon resonance (Rich et al., 2001).

The protein arrays are made by immobilizing antibodies or ligands in distinct spots on solid substratum. On incubation with a mixture of sample proteins, which are either directly or indirectly labeled with an enzyme or dye, the array is subjected to detection of protein binding by either fluorescence, light generation or colorimetric readout. The intensity of signal at every interaction spot is proportional to the concentration of the target protein in the sample mixture.

An important requisite for proteomic arrays is specific antibodies with high affinities and low dissociation rates, which can allow detection over a wide concentration range. Enzyme-liked immunosorbent assay (ELISA) has been the most preferred technology for most clinical and research applications. This is, for most part, due to its versatility and the wide availability of instrumentation. It is little surprise therefore, that there have been attempts to adapt arraybased technologies to ELISA-like formats for proteomic analysis (Mendoza et al., 1999). Such high-throughput ELISA protein array systems (Silzel et al., 1998; Chiem et al., 1998; Lueking et al., 1999; Rowe et al., 1999) comprise optically flat amino-terminal-modified glass plates arrayed with as many as 14,000 addressable antibody spots. Each spot detects a different protein partner through a fluorescently tagged secondary antibody. This format can detect unique target proteins from a mixture of numerous proteins in a high-throughput manner. An obvious extension will be to build antibody arrays to detect post-translationally modified ('activated') forms of proteins (such as phosphorylated forms), with the labeled substrates of these activated proteins as 'reporters'. This will permit global pathway profiling for cellular signal transduction in a given tissue. An example of this is the microprinted protein array for kinase activity assay. MacBeath and Schreiber used a high-precision contact-printing robot to deliver nanoliter volumes of protein samples to the slides at high spatial densities (MacBeath et al., 2000). The covalently attached proteins were shown to retain their ability to interact specifically with other proteins, as demonstrated by their ability to identify the substrates of protein kinases, and to identify the protein targets of small molecules.

Novel technologies are emerging to detect antibodyprotein interactions at high sensitivity without the need for label. We have developed one such label-free technology, which utilizes optically detectable deflection of microcantilevers following specific antigen-antibody interaction (Wu et al., 2001). In another technology, atomic force microscopy (AFM) arrays topographically image and map the protein interactions (Jones et al., 1998; Silzel et al., 1998). This is achieved by analyzing surface modulation where the increase in 'height' results from the successful 
capture of the protein within the discrete bait area. Other classes of protein arrays under development include gelimmobilized arrays (Vasiliskov et al., 1999) and fiber optic sensing arrays (Shriver-Lake et al., 1993; Wadkins et al., 1998), multiplexed capillary-based flow immunosensors and multiplexed microbead antibody capture technologies (Fulton et al., 1997; Narang et al., 1998; Carson et al., 1999). These technologies add a third-dimensional space (spherical, cylindrical or elongated domains), thereby expanding the surface area available for interaction.

Another, more cellular, level of protein profiling can be achieved by tissue array. Molecular analyses such as in situ hybridization or immunostaining are slow, cumbersome, require extensive manual interaction and are hampered by the limitation that only about 300 five- $\mu$ sections can be cut from an average-sized clinical tissue specimen. This would translate in capability for analysis of 300 molecular targets, corresponding to a mere $0.75 \%$ of all of the estimated 40,000 genes in the human genome. In order for these tissue-based analyses to become comparably high-throughput to keep pace with techniques of genomics and proteomics, Kallionemi and collaborators developed the tissue microarray (TMA) technology (Kallioniemi et al., 2001). TMAs facilitate examination of protein expression patterns in thousands of tissue specimens in an extraordinarily parallel fashion. TMAs are constructed in two steps: first, cylindrical core specimens are created from up to 1000 fixed, paraffin-embedded tissue specimens, and subsequently, these are arrayed at high density into a recipient TMA paraffin block. Up to 300 consecutive sections are then cut from each TMA block and probed with multiple reagents. The number of TMA slides can be further increased by constructing dozens of replicate TMA blocks. This is achieved by sampling each donor block a number of times and positioning the tissues at identical topographic locations in all TMAs. A single TMA experiment can thus yield protein signatures for up to a thousand specimens at once. Notably, the ability to use archival specimens in high-throughput molecular analyses is a significant advantage.

\section{Drug Discovery}

Structural Genomics: Structure Based Target Identification and Drug Discovery

Structural genomics applies high-throughput computer programs that use genomic sequences to predict how the proteins will fold, with the goal of systematically cataloguing the cellular protein interactions. While, on one hand, structural proteomics has developed through outstanding contributions from X-ray diffraction crystallography and NMR spectroscopy, structural genomics has been increasing the throughput in recent times. With increasing participation from information technology companies like IBM, Hitachi, Compaq, Hewlett-Packard, etc., structural maps will become available for a large number of proteins. Powerful computers and robots will be increasingly used in this in silico drug designing revolution. This information will provide drug designers with new targets. The use of computer simulation in pharmaceutical research will enable investigators to anticipate potential issues in the drug discovery process, such as possible drug interactions, and to select the best overall design principles in advance of real-life studies. The molecular pathways that can be dissected using such simulations include crucial cascade of cellular signaling composed of extracellular ligand interactions with their membrane receptors, transmembrane signaling, intracellular signaling via second messengers and, finally, interaction of the secondary messengers with the target genes.

\section{Functional Genomics: Mechanism Based Target Identification and Drug Discovery}

Mechanism based approaches have been attempted for some time now in various disorders, including cancer. Antimetabolite drugs were developed based on understanding of critical enzymatic steps in nucleotide synthesis. Newer such agents like gemcitabine for cancer will continue to be used effectively in clinics. Following discovery of numerous important genes involved in tumorigenesis and tumor growth, the research emphasis has shifted to molecular profiling to catalog distinct areas of signal transduction, cell-cycle regulation, angiogenesis, apoptosis or telomere maintenance and proliferation. The therapeutic focus has consequently changed to target one or more of these pathways specifically. Knowledge of the signaling pathways, for example, can provide useful targets for drugs, some examples of which are described briefly below. The advent of recombinant proteins and monoclonal antibodies is already promising to be highly useful in therapeutics. Trastuzumab (Herceptin) is one such example (Colomer et al., 2001). The role of estrogen receptors in some breast cancers was recognized in the early 1930's. This resulted in development of tamoxifen, an antagonist of the estrogen receptor, for adjuvant therapy of breast cancer. While Tamoxifen reduces recurrence in estrogen receptor positive breast cancers, resistance to tamoxifen inevitably occurs. This led to a quest for an alternative therapy for breast cancer. Nearly a third of breast cancers show over-expression of the HER-2 protein, which in most cases is due to amplification of the HER-2 gene in those tumor cells. Genentech scientists developed Trastuzumab, a monoclonal antibody directed against the extracellular domain of the HER-2 receptor, which has received FDA approval to be used in treatment of $30 \%$ breast cancers that show HER-2 positivity (Pegram et al., 2000). Trastuzumab (Herceptin) acts through HER-2 downregulation and internalization, with induction of cellcycle inhibitors like p27. If a breast cancer patient has a tumor that is HER-2 positive, then trastuzumab may be an effective therapy. If the breast cancer patient's tumor is HER-2 negative, then trastuzumab will not be effective (Piccart et al., 2001). Thus, breast cancer patients can be tested to determine if they are likely candidates for this therapy.

Use of an attenuated adenovirus ONYX-015 (Cathomen et al., 2000) harboring partially deleted E1b55k gene is another success story. Normal E1b protein interacts with another viral protein, E4ORF6, to inactivate tumor suppressor protein p53 (Bischoff et al., 1996). ONYX-015, by virtue of its deficient $\mathrm{E} 1 \mathrm{~b}$ protein, allows the attenuated virus to selectively replicate in cells with mutant p53 -a 
hallmark of most human cancers- and cause tumor cell killing.

Antisense oligonucleotides directed against mRNA for crucial regulatory proteins offer an alternative to target proteins that may not be amenable to development of small molecule inhibitors. Bcl-2, an inhibitor of apoptosis, is overexpressed in most cancers and is associated with chemoresistance. Antisense Bcl-2 compound G3139 effectively lowers Bcl-2 RNA expression in tissues, and is shown to be therapeutically effective (Duggan et al., 2001).

\section{Conclusion}

Basic research discoveries on the fundamental mechanisms responsible for a disorder are leading to the most direct pharmaceutical approaches to develop rationally designed drugs and manage the disorder. We will glean more knowledge about therapeutic benefits and side effects of these 'new drugs' through clinical trials. Increasing understanding in biomedical research has led to incredible technological advances that have up-graded almost all bio-molecular tools to a high-throughput scale. The development of newer and faster technologies is expanding our molecular genetic databases. The rapid accumulation of human gene sequences and transcriptional and translational profiles is expected to find new targets for improved interventions and hence drug discovery. Therapeutic agents with specific molecular functions can now be produced. Individual genetic profiling will thus help rational drug design and make individualized therapeutic regimens possible. Technologies such as SNP analysis, expression arrays, standardized RT-PCR, etc. will dominate the coming years of medical research and yield valuable information which will allow harnessing each patient's genetic and physiological make-up to influence management of his/her disease. In summation, pharmacogenomics has a potential to make current and future drugs safer and more effective by targeting them to patients who will benefit the most from them.

The first complete sequence of the human genome will soon be available. The impact of genomics on healthcare will be huge, with a promise of new molecularly designed drugs. Agents directed against tyrosine kinases (either as small molecules kinase inhibitors or as antibodies) are joining the anticancer armory along with antisense oligos, aptamers and ribozymes. An increased application of target tissue genotyping will guide the choice of therapy, with the ultimate aim of finding the right drug to match the right disorder and right patient. There will be changes in the process of drug discovery and development. Undesirable drug properties could be predicted earlier on during the development, leading to cost and time-saving due to toxicities. Genomic profiling and molecular profiling, with inputs from computational predictive analysis, will help these developments. It can be expected that an accurate link between molecular profile and clinical outcome will substantially lower the costs associated with clinical trials, which, in turn, will allow faster movement of novel drugs from laboratory to bedside.

The objective of pharmacogenomics is to define the pharmacological significance of genetic variation among individuals and to utilize this information in drug discovery and development. Besides decreasing the number of adverse drug responses, more effective therapeutic agents can be developed through this process. All of this is expected to result in significant cost reduction in healthcare (Flanagan 2000; Barrett 2000). It cannot, of course, be overemphasized that high premium must be placed on strict regulations of the process of collection of individual molecular profiles. There must be due diligence in maintenance of patient confidentiality while ensuring that genotype information and molecular profiles are collected for medical purposes only and remain the exclusive property of the patient. Given the prospect of advantages of patient profiling to medical practitioners, this won't be an easy task (Rothstein 1998). The same ethical, social and legal issues that relate to practice of gene therapy will have to be resolved for social acceptance of the pharmacogenomic technology. Existence of genetically distinct races is a reality. So is the existence of genetic variations of pharmacological significance known to occur in varying frequency in groups categorized by their ethnicity (Evans et al., 1999; Meyer 2000). While use of patients in clinical trials that are genotypically similar will help determine which groups are most likely to benefit from a particular drug, important issues regarding ethicality of inclusion or exclusion of specific ethnic groups and designing appropriate clinical trial sizes will have to be addressed (Noah 2000). If clinical trials are conducted with smaller-than-optimally-informative sample sizes, a drug could reach the market with inadequate information about the side effects or risk to patients who were not genotypically represented in the clinical trial.

Use of pharmacogenomic genotyping to pigeonhole patients as 'difficult to treat', 'less profitable to treat', or 'more expensive to treat' must be prevented, otherwise this could act as a barrier to the recruitment of research participants. It must also be recognized that ethnic groups characterized by 'less-profitable' genotypes are at risk of becoming 'therapeutic orphans'. Also to be understood is the possibility that this 'double-edged sword' can equally adversely impact both physicians and pharmacologists if not used properly. They might be subject to liability if they lack sufficient knowledge of genetics to adequately interpret diagnostic tests, fail to prescribe appropriate dosages or to consider drug-drug interactions, or ignore patient confidentiality. As long as it is recognized that with greater knowledge comes greater responsibility, pharmacogenomics will raise the standard of care by matching 'right drug' to 'right patient'.

\section{References}

Editorial. 1997. The cost of adverse drug reactions. Adverse Drug React. Toxicol. Rev. 16: 75-78.

Apostolakos, M.J. Schuermann, W.H.T. Frampton, M.W. Utell, M.J., and Willey, J.C. 1994. Measurement of gene expression by multiplex competitive polymerase chain reaction. Anal. Biochem. 213: 277-284.

Arenkov, P. Kukhtin, A. Gemmell, A. Voloshchuk, S. Chupeeva, V., and Mirzabekov A. 2000. Protein microchips: Use for immunoassay and enzymatic 
reactions. Anal. Biochem. 278: 123-131.

Banks, R.E. Dunn, MJ. Forbes, M.A. Stanley, A. Pappin, D. Naven, T. Gough, M. Harnden, P., and Selby P.J. 2000.

The potential use of laser capture microdissection to selectively obtain distinct populations of cells for proteomic analysis. Electrophoresis. 20: 689-700.

Barrett, A. 2000. The pharma frenzy: in the race for genebased therapies, big drug-makers join forces with upstarts. Business Week June: 160-161.

Bertilsson, L. Dahl, M.L. Sjoqvist, F. Aberg.Wistedt, A. Humble, M. Johansson, I. Lundqvist, E., and IngelmanSundberg, M. 1993. Molecular basis for rational megaprescribing in ultra-rapid hydroxylators of debrisoquin. Lancet. 341: 363.

Bischoff, J. R. Kirn, D. H. Williams, A. Heise, C. Horn, S. Muna, M. Ng, L. Nye, J. A. Sampson-Johannes, A. Fattaey, A., and McCormick, F. 1996. An adenovirus mutant that replicates selectively in p53-deficient human tumour cells. Science. 274: 373-376.

Bowater, R.P., and Wells, R.D. 2001. The intrinsically unstable life of DNA triplet repeats associated with human hereditary disorders. Prog. Nucleic Acid Res. Mol. Biol. 66: 159-202.

Boyle, M.D. Romer, T.G. Meeker, A.K., and Sledjeski, D.D. 2001. Use of surface-enhanced laser desorption ionization protein chip system to analyze streptococcal exotoxin B activity secreted by Streptococcus pyogenes. J. Microbiol. Methods. 46:87-97.

Broly, F. Gaedigk, A. Heim, M. Eichelbaum, M. Morike, K., and Meyer, U.A. 1991. Debrisoquine/sparteine hydroxylation genotype and phenotype: Analysis of common mutations and alleles of CYP2D6 in European population. DNA Cell. Biol. 10: 545-558.

Brown, P.O., and Botstein, D. 1999. Exploring the new world of the genome with DNA microarrays. Nature Genet. 21: 33-7.

Capaldi, S. Getts, R.C., and Jayasena, S.D. 2000. Signal amplification through nucleotide extension and excision on a dendritic DNA platform. Nucleic Acids Res. 28: E21.

Carson, R.T., and Vignali, D.A. 1999. Simultaneous quantitation of 15 cytokines using a multiplexed flow cytometric assay. J. Immunol. Methods. 227: 41-52.

Cathomen, T., and Weitzman, MD. 2000. A functional complex of adeno-virus proteins E1B-55kDa and E4orf6 is necessary to modulate the expression level of p53 but not its transcriptional activity. J. Virol. 74: 11407-11412.

Chiem, N.H., and Harrison, D.J. 1998. Microchip systems for immunoassay: an integrated immunoreactor with electrophoretic separation for serum theophylline determination. Clin. Chem. 44: 591-598.

Claverie, J.M. 2001. What if there are only 30,000 human genes? Science. 291: 1255-7.

Colomer, R. Shamon, L.A. Tsai, M.S., and Lupu, R. 2001. Herceptin: from the bench to the clinic. Cancer Invest. 19: 49-56.

Dahl, M.L., and Sjoqvist, F. 2000. Pharmacogenetic methods as a complement to therapeutic monitoring of antidepressants and neuroleptics. Ther. Drug. Monit. 22: 114-117.

Dahl, M.L. Johansson, I. Porsmyr Palmertz, M. IngelmanSundberg, M., and Sjoqvist, F. 1992. Analysis of the
CYP2D6 gene in relation to debrisoquine and desipramine hydroxylation in a Swedish population. Clin. Pharmacol. Ther. 51: 12-17.

Davies, H.A. 2000. The protein chip system from Ciphergen: a new technique for rapid, micro-scale protein biology. J. Mol. Med. 78: B29.

Drummond, J.T. 1999. Genomic amplification of the human DHFR/MSH3 locus remodels mismatch recognition and repair activities. Adv. Enz. Regul. 39: 129-41.

Duggan, B.J. Maxwell, P. Kelly, J.D. Canning, P., anderson, N.H. Keane, P.F. Johnston, S.R., and Williamson, K.E. 2001. The effect of antisense Bcl-2 oligonucleotides on $\mathrm{Bcl}-2$ protein expression and apoptosis in human bladder transitional cell carcinoma. J. Urol. 166: 1098-105.

Ekins, R., and Chu, F.W. 1991. Multianalyte microspot immunoassay-microanalytical 'compact disk' of the future. Clin. Chem. 37: 1955-1967.

Ekins, R., and Chu, R.W. 1997. In: Principals and Practices of Immunoassays 2nd Edn, Eds Price, C. P., and Newman, D. J. Stockton, New York.p. 625-646.

Ekins, R., and Chu, F.W. 1999. Microarrays: their origins and applications. Trends. Biotechnol. 17: 217-218.

Emmert-Buck, M.R. Gillespie, J.W. Paweletz, C.P. Ornstein, D.K. Basrur, V. Appella, E. Wang, Q.H. Huang, J. Hu, N. Taylor, P., and Petricoin, E.F. 3rd. 2000. An approach to the proteomic analysis of human tumors. Mol. Carcinogen. 27: 158-165.

Evans, D.A.P. Manley, K.A., and McKusick, V.A. 1960. Genetic control of isoniazid metabolism in man. Br. Med. J. 2: 485-491.

Evans, W.E., and Relling, M.V. 1999. Pharmacogenomics: translating functional genomics into rational therapeutics. Science. 286: 487-491.

Flanagan, A. 2000. Screening technologies evolve: innovations spurred by race to profit from genetic data. Genet. Eng. News. 20: 19-20.

Fulton, R.J. McDade, R.L. Smith, P.L. Kienker, L.J., and Kettman, J.R. Jr. 1997. Advanced multiplexed analysis with the FlowMetrix system. Clin. Chem. 43: 1749-1756. Gorlick, R. Metzger, R. Danenberg, K.D. Salonga, D. Miles, J.S. Longo, G.S. Fu, J. Banerjee, D. Klimstra, D. Jhanwar, S. Danenberg, P.V. Kemeny, N., and Bertino, J.R. 1998. Higher levels of thymidylate synthase gene expression are observed in pulmonary as compared with hepatic metastases of colorectal adenocarcinoma. J.Clin.Oncol. 16: 1465-1469.

Grant, D.M., and Phillips, M.S. 2001. Technologies for the analysis of single-nucleotide polymorphisms: an overview. In: Pharmacogenomics. Eds. Kalow, Meyer and Tyndale. Published by Marcel Dekker, Inc. New York, volume 113, pages 183-190.

Green, C.D. Fredrik, J.S. Taillon, B.E.and Lewin, D.A. 2001. Open Systems: Panoramic Views of Gene Expression. J. Immunol. Methods. 250: 67-79.

Gygi, S.P. Rist, B. Gerber, S.A. Turecek, F. Gelb, M.H., and Aebersold, R. 1999. Quantitative analysis of complex protein mixtures using isotope-coded affinity tags. Nature Biotechnol. 17: 994-999.

Hacia, J.G. Brody, L.C. Chee, M.S. Fodor, S.P., and Collins, F.S. 1996. Detection of heterozygous mutations in BRCA1 using high density oligonucleotide arrays and two-colour 
fluorescence analysis. Nature Genet. 14: 441-7.

Hancock, W. Apffel, A. Chakel, J. Hahnenberger, K. Choudhary, G. Traina, J.A., and Pungor, E. 1999. Integrated genomic/proteomic analysis. Anal. Chem. 71, 743-748.

Heim, M.H., and Meyer, U.A. 1990. Genotyping of poor metabolizers of debrisoquine by allele specific PCR amplification. Lancet. 336: 529-532.

Humphery-Smith, I. Cordwell, S.J., and Blackstock, W.P. 1997. Proteome research: Complementarity and limitations with respect to the RNA and DNA worlds. Electrophoresis. 18: 1217-1242.

Iqbal, S., and Lenz, H.J. 2001. Determinants of prognosis and response to therapy in colorectal cancer. Curr. Oncol. Reports. 3: 102-108

lyer, L. King, C.D. Whitington, P.F. Roy, S.K. Green, M.D. Tephly, T.R. Coffman, B.L., and Ratain, M.J. 1998. Genetic predisposition to the metabolism of irinotecan: role of UGT1A1 in the glucuronidation of its active metabolite (SN-38) in human liver microsomes. J. Clin. Invest. 101: 847-854.

Johnston, P. Lenz, H.J. Leichman, C.G. Danenberg, K.D. Allegra, C.J. Danenberg, P.V., and Leichman, L. 1995. Thymidylate synthase gene and protein expression correlate and are associated with response to 5fluorouracil in human colorectal and gastric tumors. Cancer. Res. 55: 1407-1412.

Jones, V.W. Kenseth, J.R. Porter, M.D. Mosher, C.L., and Henderson, E. 1998. Microminiaturized immunoassays using atomic force microscopy and compositionally patterned antigen arrays. Anal. Chem. 70: 1233-1241.

Kallioniemi, O.P. Wagner, U. Kononen, J., and Sauter, G. 2001. Tissue microarray technology for high-throughput molecular profiling of cancer. Human Molecular Genetics. 10: 657-62.

Lazarou, J. Pomeranz, B.H., and Corey, P.N. 1998. Incidence of adverse drug reactions in hospitalized patients: a meta-analysis of prospective studies. J. A. M. A. 279: 1200-1205.

Leichman, C.G. Lenz, H.J. Danenberg, K.D. Leichman, L. Danenberg, K.D. Baranda, J. Groshen, S. Boswell, W. Metzger, R. Tan, M., and Danenberg, P.V. 1997. Quantitation of intratumoral thymidylate synthase expression predicts for disseminated colorectal cancer response and resistance to protracted infusion fluorouracil and weekly leucovorin. J. Clin. Oncol. 15: 3223-3229.

Lenz, H.J. Hill, C. Danenberg, K.D. Leichman, L.L. Priest, D.G., and Danenberg, P.V. 1995. Rapid quantitative PCR for determination of relative gene expressions in tissue specimens. PCR Meth. Appl. 4: 305-309.

Liang, P., and Pardee, A.B. 1992. Differential display of eukaryotic messenger RNA by means of the polymerase chain reaction. Science. 257: 967-971.

Lockhart, D.J. Dong, H. Byrne, M.C. Follettie, M.T. Gallo, M.V. Chee, M.S. Mittmann, M. Wang, C. Kobayashi, M. Horton, and H. Brown, E.L. 1996. Expression monitoring by hybridization to high-density oligonucleotide arrays. Nature Biotech. 14: 1675-80.

Lueking, A. Horn, M. Eickhoff, H. Bussow, K. Lehrach, H., and Walter, G. 1999. Protein microarrays for gene expression and antibody screening. Anal. Biochem. 270:
103-111.

Luo, L. Salunga, R.C. Guo, H. Bittner, A. Joy, K.C. Galindo, J.E. Xiao, H. Rogers, K.E. Wan, J.S. Jackson, M.R., and Erlander, M.G. 1999. Gene expression profiles of lasercaptured adjacent neuronal subtypes. Nature Med. 5, 117122.

MacBeath, G., and Schreiber, S. L. 2000 Printing Proteins as Microarrays for High-Throughput Function Determination. Science. 289: 1760-1763.

Mahgoub, A. Idle, J.R. Dring, L.G. Lancaster, R., and Smith, R.L. 1977. Polymorphic hydroxylation of debrisoquine in man. Lancet. 2: 584-586.

Mendoza, L.G. McQuary, P. Mongan, A. Gangadharan, R. Brignac, S., and Eggers, M. 1999. High throughput microarray based enzyme linked immunosorbant assay. BioTechniques. 27: 778-788.

Meyer, U.A. 2000. Pharmacogenetics and adverse drug reactions. Lancet 356, 1667-1671.

Murakami, T. Hagiwara, T. Yamamoto, K. Hattori, J. Kasami, M. Utsumi, M., and Kaneda, T. 2001. A novel method for detecting HIV-1 by non-radioactive in situ hybridization: application of a peptide nucleic acid probe and catalysed signal amplification. J. Pathol. 194: 130-5.

Narang, U. Gauger, P.R. Kusterbeck, A.W., and Ligler, F.S. 1998. Multianalyte detection using a capillary-based flow immunosensor. Anal. Biochem. 255: 13-19.

Noah, B.A. 2000. Adverse drug reactions: harnessing experiential data to promote patient welfare. Catholic $U$. Law Rev. 49: 449-504.

Page, M.J. Amess, B. Townsend, R.R. Parekh, R. Herath, A. Brusten, L. Zvelebil, M.J. Stein, R.C. Waterfield, M.D. Davies, S.C., and O'Hare, M.J. 1999. Proteomic definition of normal human luminal and myoepithelial breast cells purified from reduction mammoplasties. Proc. Natl. Acad. Sci. USA. 96: 12589-12594.

Paweletz, C.P. 2000. (SELDI) Biomarker profiling of stages of cancer progression directly from human tissue using a protein biochip. Drug Develop. Res. 49: 34-42.

Pease, A.C. Solas, D. Sullivan, E.J. Cronin, M.T. Holmes, C.P., and Fodor, S.P. 1994. Light-generated oligonucleotide arrays for rapid DNA sequence analysis. Proc. Natl. Acad. Sci. USA. 91: 5022-6.

Pegram, M.D. Konecny, G., and Slamon, D.J. 2000. The molecular and cellular biology of HER2/neu gene amplification/overexpression and the clinical development of herceptin (trastuzumab) therapy for breast cancer. Cancer Treatment and Research. 103: 57-75.

Peltomaki, P. 2001. Deficient DNA mismatch repair: a common etiologic factor for colon cancer. Deficient DNA mismatch repair: a common etiologic factor for colon cancer. Hum. Mol. Genet. 10: 735-40.

Piccart, M. Lohrisch, C. Di Leo, A., and Larsimont, D. 2001. The predictive value of HER2 in breast cancer. Oncology. 61: 73-82.

Rich, R.L. Day, Y.S. Morton, T.A., and Myszka, D.G. 2001. High-resolution and high-throughput protocols for measuring drug/human serum albumin interactions using BIACORE. Anal Biochem. 296: 197-207.

Rolfs, A. Schuller, I. Finckh, U., and Weber-Rolfs, I. 1992. PCR: Clinical diagnostics and research. Springer-Verlag, Berlin. p. 1-271. 
Rooney, P.H. Stevenson, D.A. Marsh, S. Johnston, P.G. Haites, N.E. Cassidy, J., and McLeod, H.L. 1998. Comparative genomic hybridization analysis of chromosomal alterations induced by the development of resistance to thymidylate synthase inhibitors. Cancer Res. 58: 5042-5045.

Rothstein, M.A. 1998 Genetic privacy and confidentiality: why they are so hard to protect. J. Law Med. Ethics 26: 198-204.

Rowe, C.A. Tender, L.M. Feldstein, M.J. Golden, J.P. Scruggs, S.B. MacCraith, B.D. Cras, J.J., and Ligler, F.S. 1999. Array biosensor for simultaneous identification of bacterial, viral, and protein analytes. Anal. Chem. 71: 3846-3852.

Salonga, D. Danenberg, K.D. Johnson, M. Metzger, R. Groshen, S. Tsao-Wei, D.D. Lenz, H.L. Leichman, C.G. Leichman, L. Diasio, R.B., and Danenberg, P.V. 2000. Gene expression levels of dihydropyrimidine dehydrogenase and thymidylate synthase together identify a high percentage of colorectal tumors responding to 5-fluorouracil. Clin. Cancer Res. 6: 1322-1327.

Shriver-Lake, L.C. Ogert, R.A., and Ligler, F.S. 1993. A fiber optic evanescent-wave immunosensor for large molecules. Sensors Actuators. 11: 239-243.

Silzel, J.W. Cercek, B. Dodson, C. Tsay, T., and Obremski, R.J. 1998. Mass-sensing multianalyte microarray immunoassay with imaging detection. Clin. Chem. 44: 2036-2043.

Southern, E.M. 1975. Detection of specific sequences among DNA fragments separated by gel electrophoresis. J. Mol. Biol. 98: 503-17.

Southern, E.M. Case-Green, S.C. Elder, J.K. Johnson, M. Mir, K.U. Wang, L., and Williams, J.C. 1994. Arrays of complementary oligonucleotides for analysing the hybridisation behaviour of nucleic acids. Nucleic Acids Res 22: 1368-73.

The international human genome mapping consortium. 2001. A physical map of the human genome. Nature. 409,
934-941.

Tsujitani, S. Konishi, I. Suzuki, K. Oka, S. Gomyo, Y. Matsumoto, S. Hirooka, Y., and Kaibara, N. 2000. Expression of thymidylate synthase in relation to survival and chemosensitivity in gastric cancer patients. J. Exp. Clin. Canc. Res. 19: 189-95.

Van Triest, B. Pinedo, H.M. Giaccone, G., and Peters, G.J. 2000. Downstream molecular determinants of response to 5 fluorouracil and antifolate thymidylate synthase inhibition. Annals Oncol. 11:385-391.

Vasiliskov, A. V. Timofeev, E.N. Surzhikov, S.A. Drobyshev, A.L. Shick, V.V., and Mirzabekov, A.D. 1999. Fabrication of microarray of gel-immobilized compounds on a chip by copolymerization. BioTechniques. 27: 592-606.

Volkenandt, M. Dicker, A.P. Banerjee, D. Fanin, R. Schweitzer, B. Horikoshi, T. Danenberg, K. Danenberg, P., and Bertino, J.R. 1992. Quantitation of gene copy number and mRNA using the polymerase chain reaction. Proc. Soc. Exp. Biol. Med. 200: 1-6.

Wadkins, R.M. 1998. Biosensors and bioelectronics: detection of multiple toxic agents using a planar array. Immunosensor. 13: 407-415.

Weinshilboum, R. 2001. Thiopurine pharmacogenetics: clinical and molecular studies of thiopurine methyl transferase. Drug Metabolism and Dispos. 29: 601-605.

Willey, J.C. Crawford, E.L. Jackson, C.M. Weaver, D.A. Hoban, J.C. Khuder, S.A., and DeMuth, J.P. 1998. Expression Measurement of Many Genes Simultaneously by Quantitative RT-PCR Using Standardized Mixtures of Competitive Templates. Am. J. Respir. Cell. Mol. Biol. 19: 6-17.

Wolf, C.R. Smith, G., and Smith, R.L. 2000. Science, medicine and the future: pharmacogenetics. Brit. Med. J. 320: 987-990.

Wu, G., Datar, R.H., Hansen, K.M., Thundat, T., Cote, R.J., and Majumdar, A. 2001. Bioassay of prostate-specific antigen (PSA) using microcantilevers. Nature Biotechnol. 19: 856-860. 


\section{Further Reading}

Caister Academic Press is a leading academic publisher of advanced texts in microbiology, molecular biology and medical research. Full details of all our publications at caister.com

- MALDI-TOF Mass Spectrometry in Microbiology Edited by: M Kostrzewa, S Schubert (2016) www.caister.com/malditof

- Aspergillus and Penicillium in the Post-genomic Era Edited by: RP Vries, IB Gelber, MR Andersen (2016) www.caister.com/aspergillus2

- The Bacteriocins: Current Knowledge and Future Prospects Edited by: RL Dorit, SM Roy, MA Riley (2016)

www.caister.com/bacteriocins

- Omics in Plant Disease Resistance Edited by: V Bhadauria (2016) www.caister.com/opd

- Acidophiles: Life in Extremely Acidic Environments Edited by: R Quatrini, DB Johnson (2016) www.caister.com/acidophiles

- Climate Change and Microbial Ecology: Current Research and Future Trend

Edited by: J Marxsen (2016)

www.caister.com/climate

- Biofilms in Bioremediation: Current Research and Emerging Technologies

Edited by: G Lear (2016)

www.caister.com/biorem

- Microalgae: Current Research and Applications Edited by: MN Tsaloglou (2016) www.caister.com/microalgae

- Gas Plasma Sterilization in Microbiology: Theory, Applications, Pitfalls and New Perspectives Edited by: H Shintani, A Sakudo (2016) www.caister.com/gasplasma

- Virus Evolution: Current Research and Future Directions Edited by: SC Weaver, M Denison, M Roossinck, et al. (2016) www.caister.com/virusevol

- Arboviruses: Molecular Biology, Evolution and Control Edited by: N Vasilakis, DJ Gubler (2016) www.caister.com/arbo

- Shigella: Molecular and Cellular Biology Edited by: WD Picking, WL Picking (2016) www.caister.com/shigella

-Aquatic Biofilms: Ecology, Water Quality and Wastewater Treatment

Edited by: AM Romaní, H Guasch, MD Balaguer (2016)

www.caister.com/aquaticbiofilms

- Alphaviruses: Current Biology

Edited by: S Mahalingam, L Herrero, B Herring (2016)

www.caister.com/alpha

- Thermophilic Microorganisms

Edited by: F Li (2015)

www.caister.com/thermophile
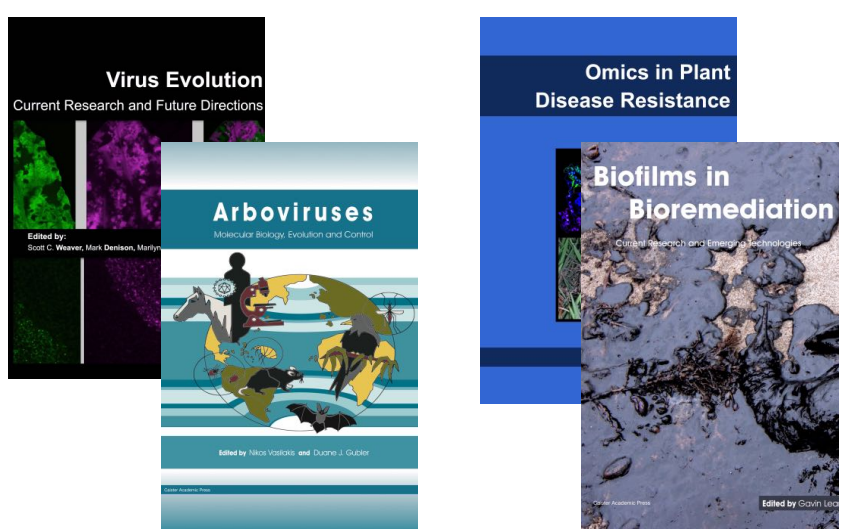
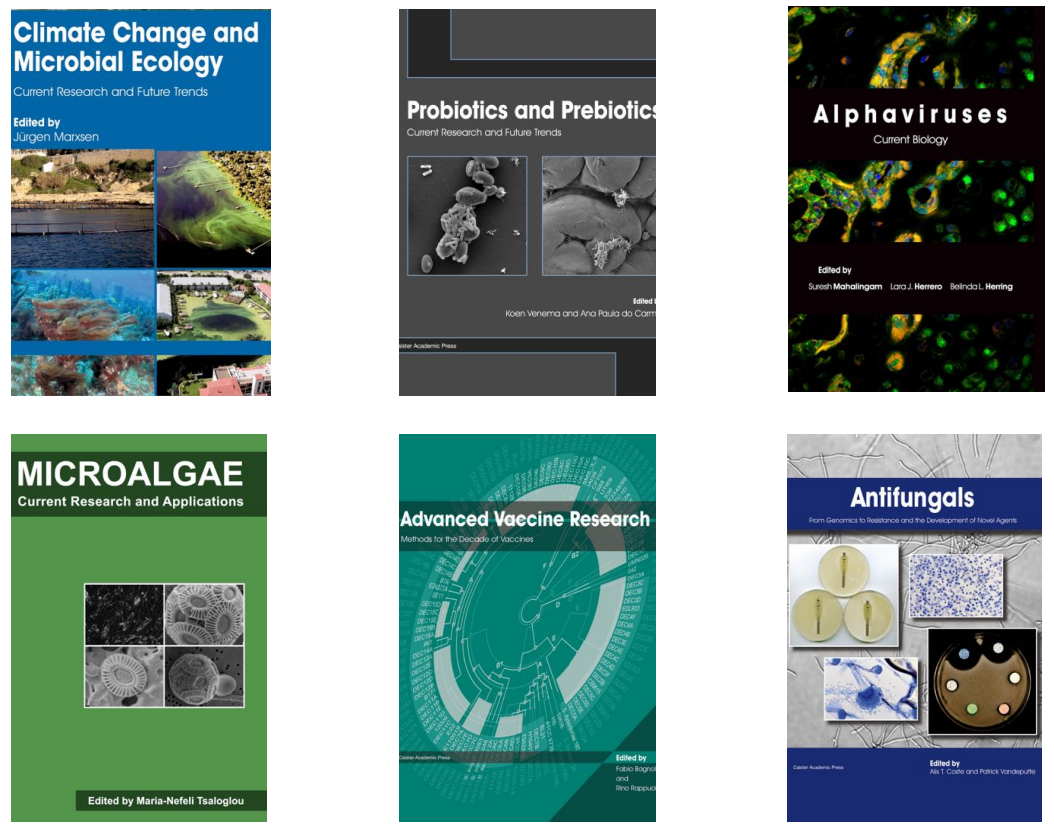

- Flow Cytometry in Microbiology: Technology and Applications Edited by: MG Wilkinson (2015) www.caister.com/flow

- Probiotics and Prebiotics: Current Research and Future Trends Edited by: K Venema, AP Carmo (2015) www.caister.com/probiotics

- Epigenetics: Current Research and Emerging Trends Edited by: BP Chadwick (2015) www.caister.com/epigenetics2015

- Corynebacterium glutamicum: From Systems Biology to Biotechnological Applications

Edited by: A Burkovski (2015)

www.caister.com/cory2

- Advanced Vaccine Research Methods for the Decade of Vaccines

Edited by: F Bagnoli, R Rappuoli (2015)

www.caister.com/vaccines

- Antifungals: From Genomics to Resistance and the Development of Novel Agents

Edited by: AT Coste, P Vandeputte (2015)

www.caister.com/antifungals

- Bacteria-Plant Interactions: Advanced Research and Future Trends Edited by: J Murillo, BA Vinatzer, RW Jackson, et al. (2015) www.caister.com/bacteria-plant

\section{- Aeromonas}

Edited by: J Graf (2015)

www.caister.com/aeromonas

- Antibiotics: Current Innovations and Future Trends

Edited by: S Sánchez, AL Demain (2015)

www.caister.com/antibiotics

- Leishmania: Current Biology and Contro Edited by: S Adak, R Datta (2015) www.caister.com/leish2

- Acanthamoeba: Biology and Pathogenesis (2nd edition) Author: NA Khan (2015)

www.caister.com/acanthamoeba2

- Microarrays: Current Technology, Innovations and Applications Edited by: Z He (2014)

www.caister.com/microarrays2

- Metagenomics of the Microbial Nitrogen Cycle: Theory, Methods and Applications

Edited by: D Marco (2014)

www.caister.com/n2 